\title{
Risk Simulation of Soil Contamination by Polycyclic Aromatic Hydrocarbons from Sewage Sludge used as Fertilizers
}

\author{
Lourival C. Paraíba, Sonia C. N. Queiroz,* Débora R. C. de Souza and Maria L. Saito \\ Embrapa Meio Ambiente, Rodovia SP 340, km 127,5, Tanquinho Velho, CP 69, \\ 13820-000 Jaguariúna-SP, Brazil
}

\begin{abstract}
Este trabalho investigou a presença de 16 hidrocarbonetos policíclicos aromáticos (HPAs) em lodo de esgoto e em solo com aplicação de lodo como fertilizante agrícola e simulou o risco de contaminação por HPAs a longo prazo. As amostras foram extraídas usando diclorometano e em seguida com $n$-hexano em banho ultrassônico. A limpeza do extrato foi feita em coluna de alumina. As quantificações dos HPAs foram obtidas por cromatografia gasosa acoplada a um espectrômetro de massas (GC-MS/MS ion trap). Os resultados evidenciaram que HPAs encontrados em lodos de esgoto podem apresentar risco de contaminação de solos. As simulações das concentrações dos HPAs no solo por meio de modelos matemáticos foram utilizadas para indicar uma ordem de prioridade para monitoramento da qualidade do solo: fenantreno $>$ criseno $>$ benzo(k)fluoranteno $>$ benzo(a)pireno $>$ pireno $>$ benzo(b)fluoranteno $>$ benzo $(\mathrm{g}, \mathrm{h}, \mathrm{i})$ perileno $>$ indeno(1,2,3-c,d)pireno $>$ fluoranteno $>$ benzo(a)antraceno $>$ dibenzo(a,h)antraceno $>$ fluoreno $>$ antraceno $>$ naftaleno $>$ acenafteno $>$ acenaftileno.
\end{abstract}

This work investigated the presence of PAH in sewage sludge and in soil with sewage sludge applied as agricultural fertilizer and simulated a long-term risk of soil contamination by PAH. The samples were extracted using dichloromethane and then with $n$-hexane in ultrasonic bath. The clean-up of the extract was done on a column containing alumina. The residual PAH were obtained using a gas chromatograph coupled to a mass spectrometer (ion trap GC-MS/MS). The results evidenced that $\mathrm{PAH}$ concentration levels found in sewage sludge might raise potential contamination risks to the soil. Simulations of the concentrations of PAHs in soil, by mathematical modeling, allowed to indicate a priority order for monitoring soil quality in terms of these contaminants: phenanthrene $>$ chrysene $>$ benzo(k)fluoranthene $>$ benzo(a)pyrene $>$ pyrene $>$ benzo(b)fluoranthene $>$ benzo(g,h,i)perylene $>$ indeno(1,2,3-c,d)pyrene $>$ fluoranthene $>$ benzo(a)anthracene $>$ dibenzo(a,h)anthracene $>$ fluorene $>$ anthracene $>$ naphthalene $>$ acenaphthene $>$ acenaphthylene.

Keywords: sewage sludge, PAH, biosolid, ion trap GC-MS/MS, soil contamination

\section{Introduction}

Polycyclic aromatic hydrocarbons (PAHs) are a group of non-polar hydrophobic organic compounds comprised of two or more fused aromatic rings.

Due to their toxic, mutagenic, estrogenic, and/or carcinogenic properties, sixteen PAH compounds have been identified as pollutants by the US-EPA ${ }^{1}$ and seven of them are considered carcinogenic. ${ }^{2}$ For this reason, these organic pollutants are considered the most toxic to aquatic and terrestrial life and of high priority in environmental studies: acenaphthene, acenaphthylene, anthracene, benzo(a)anthracene, benzo(a)pyrene, benzo(b)

*e-mail: sonia@cnpma.embrapa.br fluoranthene, benzo(g,h,i)perylene, benzo(k)fluoranthene, chrysene, dibenzo(a,h)anthracene, fluoranthene, fluorene, indeno(1,2,3-c,d)pyrene, naphthalene, phenanthrene and pyrene.

Human exposure to PAHs may occur via processed foods, contaminated water and green vegetables. Fismes et al. ${ }^{3}$ demonstrated that lettuce, potato and carrot plants can absorb PAHs from contaminated soils. Camargo and Toledo ${ }^{4}$ found significant PAH levels in grapes, apples, pears, tomatoes, cabbages and lettuces grown in Brazilian rural areas nearby urban centers. Zohair et al..$^{5}$ observed PAH-contaminated potatoes and carrots from plants grown in organic cultivation systems. Farhadian et al. ${ }^{6}$ studied polycyclic aromatic hydrocarbons in grilled meat. The highest concentrations of PAHs were detected in charcoal 
grilled followed by flame-gas and oven grilled dishes. Kulhánek et al. ${ }^{7}$ used models, statistical regressions and the PAH bioconcentration factors in foods to estimate the risk of human $\mathrm{PAH}$ intake via contaminated fruits, tubers and vegetables, in order to regulate the maximum food $\mathrm{PAH}$ level in the European Community. Collins et al. ${ }^{8}$ described the main processes involved in the organic compound (including PAHs) accumulation by roots, leaves and fruits. Chouychai et al. ${ }^{9}$ studied the phenanthrene and pyrene phytotoxicity in corn and peanut plants and concluded that corn plants can be used to phytoremediate contaminated soils, meaning that corn plants are able to take up and accumulate several PAHs from soil solution. ${ }^{10}$

Sewage sludge (SS) is a complex organic by-product of the wastewater treatment process. Large amounts of SS are constantly produced and the disposal routes are a matter of worldwide concern and environmental problem. This material is supposed to be potentially useful in agricultural land amendment or degraded area recovery due to its rich nutrient composition, especially in organic matter (OM), nitrogen $(\mathrm{N})$ and phosphorus $(\mathrm{P}) .{ }^{11}$ However, there are risks and benefits associated with SS use in soils, since it contains not only OM, N and P, but also metals, microorganisms and pollutant organic compounds such as the PAHs. ${ }^{12-14}$ In general, the pollutant substances are associated with uncontrolled mixtures of domestic and industrial wastes or with the waste treatment process. ${ }^{15}$ Sewage sludge used as fertilizers might contaminate crops, soils, superficial and underground waters with nitrates, heavy metals, pathogens, various classes of organic compounds and persistent organic compounds. ${ }^{14,16,17}$ In Brazil, the use of SS in agriculture is regulated through the directive CONAMA357/2005. ${ }^{18}$

There is little information in the literature about PAH uptake by plants from SS-treated soils. Evidences of plant accumulation of organic contaminants as a result of continuous SS-addition to agricultural soils were reported, showing positive correlations between PAH concentrations of shoots, roots and the soil where plants were grown. ${ }^{15,19}$ Oleszczuk and Baran ${ }^{19}$ investigated during three years the PAH absorption by Salix viminalis and concluded that the residue concentrations found in leaves and stems were associated with the PAH content of SS added to the soil as fertilizers. The continuous PAH accumulation in soils as a consequence of the various human activities ${ }^{15,20}$ is also a matter of great concern and represents risk of plant contamination. ${ }^{19,21}$

Many PAHs were found in SS samples obtained from Wastewater Treatment Plants in Brazilian cities. ${ }^{13}$ In the State of São Paulo, the use of SS in agriculture is regulated through the technical directive $\mathrm{P} 4230$, created by CETESB ${ }^{22}$ a government environmental sanitation agency - which limits the residue disposal in soils, according to the heavy metal and nitrogen soil contents, the crop nutrient demands and the soil nitrogen mineralization rate.

Dreher ${ }^{23}$ investigated organic pollutant contamination in agricultural soils treated with SS and found high organotin and PAH concentrations in three of eleven cultivated fields and two other experimental plots. In another field, high dioxin concentrations were found. These studies evidenced that SS-organic pollutants might persist for years in the soil. Among the pollutants, Dreher ${ }^{23}$ studied the classes of PAHs, polychlorinated biphenyls, chloride pesticides, dioxins and furans, octil-nonylphenols, polycyclic mixtures, phthalates, polybrominated diphenyl ethers, organotins, linear alkylbenzene sulfonates, bisphenols, pharmaceutical products and heavy metals. Krogmann ${ }^{24}$ and Paraíba and Saito ${ }^{25}$ pointed out the need of continuous organic pollutant monitoring in sewage sludges from different origins.

Along with this land application of sewage sludge, PAHs, pharmaceuticals and other contaminants can be introduced to soils, having the potential to be transported to surface water and groundwater. Anthropogenic organic contaminants, including several PAHs, have been found in soils amended with sewage sludges. ${ }^{17}$

Experimentally validated mathematical models can demonstrate or predict the soil contamination with persistent organic pollutants from SS continuously used as agricultural fertilizer. Physicochemical characteristics such as water solubility, lipid affinity, vapor pressure, soil organic carbon sorption and half-life of organic compounds allow developing mathematical models that can predict risks of soil contamination by continuous SS applications.

This research is based on the hypothesis that sewage sludges (SS) contain persistent organic pollutants (POPs) belonging to the polycyclic aromatic hydrocarbon (PAH) class and that POPs may accumulate in SS-fertilized soils.

The objective of this study was to assess the presence of sixteen selected PAHs of concern to be monitored in soil and sewage sludges, according to US-EPA. ${ }^{1}$ Methods of residue analysis using a gas chromatograph coupled to an ion trap mass spectrometer (CG-MS/MS) were developed for the determination of selected PAHs in soil and SS samples. Soil samples were obtained from a field experimental area of Embrapa Meio Ambiente (Embrapa Environment), where a long-term experiment was carried out with corn plants grown in soils amended with SS for six consecutive years. ${ }^{11,14,26}$

\section{Experimental}

Field experiments were carried out in a clay texture distroferric red oxisol (sand loam rhodic oxisol, typic 
haplustox) at the field station of Embrapa Environment, at Jaguariúna City, São Paulo State, Brazil (22 $2^{\circ} 41^{\prime}$ S latitude, $47^{\circ} \mathrm{W}$ longitude and $570 \mathrm{~m}$ altitude). The PAH residue determinations in soil and SS samples were made in the Laboratory of Residues and Contaminant of Embrapa Environment.

Nine experimental plots of $10 \times 20 \mathrm{~m}$ cultivated with corn plants were used. The experiment was arranged in randomized complete blocks with three replications. Treatments consisted of three SS rates: (i) control plots (without SS or mineral fertilizer-STEST); (ii) plots treated with $28.15 \mathrm{t} \mathrm{ha}^{-1}$ of SS, correspondent to one regular nitrogen $(\mathrm{N})$ rate for corn crop provided by mineral fertilization (SDL1N); and (iii) plots treated with $225.2 \mathrm{t} \mathrm{ha}^{-1}$ of SS, correspondent to 8-fold the regular $\mathrm{N}$ rate for corn crop provided by mineral fertilization (SDL8N). The SS rates were calculated to supply the crop demand, based on the SS-N concentration supposing a $30 \% \mathrm{~N}$ mineralization rate, ${ }^{26}$ and on the soil available $\mathrm{N}$ concentration. The SS rates were complemented with potassium (K), according to the plant $\mathrm{K}$ demand, added as mineral fertilizer $(\mathrm{KCl})$.

The sewage sludge used in the experiments was obtained from the municipal Sanitation Plant of Franca, State of São Paulo, Brazil. Three to four days before maize sowing, the SS rates were manually applied to the field plots (SDL1N and SDL8N) and incorporated up to $15 \mathrm{~cm}$ depth by hoeing. Six soil samples were collected from each of the nine experimental plots (STEST, SDL1N and SDL8N) at $10-15 \mathrm{~cm}$ depth surface layer, where maize roots are most concentrated. A total of fifty four soil samples were air dried at room temperature and passed through $1 \mathrm{~mm}$ screen sieves. Samplings were taken $24 \mathrm{~h}$ after SS application and before maize sowing.

The soil characteristics determined in the STEST, SDL1N and SDL8N plots at $10-15 \mathrm{~cm}$ depth layer were as follows: field capacity $\theta=0.30 \mathrm{~m}^{3} \mathrm{~m}^{-3}$, organic carbon $=$ $0.015 \mathrm{~g} \mathrm{~g}^{-1}$, dry soil density $\rho_{\mathrm{Sd}}=1.25 \mathrm{~kg} \mathrm{~L}^{-1}$, humid soil density $\rho_{\mathrm{Sw}}=1.5 \mathrm{~kg} \mathrm{~L}^{-1}$ and total porosity $\delta=0.55 \mathrm{~m} \mathrm{~m}^{-3}$. These soil characteristics were used in the analysis and simulation model to obtain the risk of soil contamination by PAHs from successive yearly SS application rates.

The results of soil and SS sample analysis are shown in Table 1, referred to the following PAH physical characteristics: base 10-logarithm of octanol-water partition coefficient $\left(\log \mathrm{K}_{\mathrm{OW}}\right)$, molar mass $\left(\mathrm{M}_{\mathrm{w}} \mathrm{g} \mathrm{mol}^{-1}\right)$, water solubility $\left(\mathrm{S}_{\mathrm{w}} \mathrm{mg} \mathrm{L}^{-1}\right)$, vapor pressure $\left(\mathrm{V}_{\mathrm{p}} \mathrm{Pa}\right)$, half-life in the soil ( $\mathrm{t}_{1 / 2}$ days), and the soil organic carbon sorption coefficient $\left(\mathrm{K}_{\mathrm{OC}}\right)$.

Analytical methods for PAH determination in soil and sewage sludge samples

Methods for PAH residue determination in soil and SS samples were developed and validated by gas chromatography coupled to an ion trap mass spectrometry

Table 1. Polycyclic aromatic hydrocarbon (PAH) logarithm of octanol-water partition coefficient, water solubility, vapor pressure, half-life in soil and sorption coefficient in soil organic carbon (16 PAHs)

\begin{tabular}{|c|c|c|c|c|c|}
\hline PAH & ${ }^{\mathrm{a}} \log \mathrm{K}_{\mathrm{OW}}$ & ${ }^{\mathrm{a}} \mathrm{S}_{\mathrm{w}} /\left(\mathrm{mg} \mathrm{L}^{-1}\right)$ & ${ }^{\mathrm{a}} \mathrm{V}_{\mathrm{p}} / \mathrm{Pa}$ & ${ }^{b} t_{1 / 2} /$ days & ${ }^{\mathrm{c}} \mathrm{K}_{\mathrm{OC}} /\left(\mathrm{L} \mathrm{kg}^{-1}\right)$ \\
\hline naphthalene & 3.3 & 31.0 & $1.13 \times 10^{1}$ & 48 & 278 \\
\hline acenaphthylene & 3.9 & 16.1 & $8.91 \times 10^{-1}$ & 60 & 1054 \\
\hline acenaphthene & 3.9 & 3.9 & $2.87 \times 10^{-1}$ & 102 & 1011 \\
\hline fluorene & 4.2 & 1.6900 & $8.00 \times 10^{-2}$ & 60 & 1737 \\
\hline phenanthrene & 4.5 & 1.15 & $1.61 \times 10^{-2}$ & 200 & 3111 \\
\hline anthracene & 4.4 & 0.0434 & $8.71 \times 10^{-4}$ & 460 & 3046 \\
\hline fluoranthene & 5.1 & 0.2600 & $1.23 \times 10^{-3}$ & 440 & 11787 \\
\hline Pyrene & 4.9 & 0.135 & $6.00 \times 10^{-4}$ & 1870 & 7456 \\
\hline benzo(a)anthracene & 5.8 & 0.0094 & $2.80 \times 10^{-5}$ & 670 & 46563 \\
\hline chrysene & 5.8 & 0.0020 & $8.31 \times 10^{-7}$ & 990 & 51670 \\
\hline benzo(b)fluoranthene & 5.8 & 0.0015 & $6.67 \times 10^{-5}$ & 610 & 48542 \\
\hline benzo(k)fluoranthene & 6.1 & 0.0008 & $1.29 \times 10^{-7}$ & 2140 & 96481 \\
\hline benzo(a)pyrene & 6.1 & 0.0016 & $7.32 \times 10^{-7}$ & 530 & 100582 \\
\hline indeno(1.2.3-c.d)pyrene & 6.7 & 0.0002 & $1.67 \times 10^{-8}$ & 730 & 329458 \\
\hline dibenzo(a.h)anthracene & 6.7 & 0.0025 & $1.27 \times 10^{-7}$ & 940 & 365595 \\
\hline benzo(g.h.i)perylene & 6.6 & 0.0003 & $1.33 \times 10^{-8}$ & 650 & 284787 \\
\hline
\end{tabular}

${ }^{\mathrm{a}}$ Data obtained in SRC, Inc.; ${ }^{27}$ from Howard et al.; ${ }^{28}$ cestimated by $\log \mathrm{K}_{\mathrm{OC}}=0.901 \operatorname{og} \mathrm{K}_{\mathrm{OW}}-0.54$, from Chiou et al. ${ }^{29}$ 
(GC-MS/MS). The proposed methods were validated through the parameters of linearity, limit of detection (LOD), limit of quantification (LOQ), accuracy (recovery) and precision (repetitiveness and intermediary precision). The LOD and LOQ values in soil and SS samples are presented in Table 2.

Table 2. Limits of detection (LOD) and quantification (LOQ) of the method for the polycyclic aromatic hydrocarbons (PAHs) in the soil and sewage sludge matrices

\begin{tabular}{lcc}
\hline PAHs & $\mathrm{LOD} /\left(\mu \mathrm{g} \mathrm{kg}^{-1}\right)$ & $\mathrm{LOQ} /\left(\mu \mathrm{g} \mathrm{kg}^{-1}\right)$ \\
\hline naphthalene & 0.91 & 3.00 \\
acenaphthylene & 0.42 & 1.40 \\
acenaphthene & 0.37 & 1.20 \\
fluorene & 0.39 & 1.30 \\
phenanthrene & 0.28 & 0.89 \\
anthracene & 0.32 & 1.10 \\
fluoranthene & 0.16 & 0.53 \\
pyrene & 0.16 & 0.55 \\
benzo(a)anthracene & 0.45 & 1.50 \\
chrysene & 0.42 & 1.40 \\
benzo(b)fluoranthene & 1.60 & 5.40 \\
benzo(k)fluoranthene & 1.80 & 6.00 \\
benzo(a)pyrene & 2.50 & 8.40 \\
indeno(1,2,3-c,d)pyrene & 0.86 & 2.70 \\
dibenzo(a,h)anthracene & 0.90 & 3.00 \\
benzo(g,h,i)perylene & 0.80 & 2.80 \\
\hline
\end{tabular}

Linear equipment response was obtained for all PAH compounds in specific concentration ranges, due to the differences among analytes for the equipment detection limits. Linear concentration ranges were obtained for acenaphthene, acenaphthylene, fluorene, phenanthrene, anthracene, fluoranthene and pyrene concentrations between $0.005 \mu \mathrm{g} \mathrm{mL}^{-1}$ and $0.6 \mu \mathrm{g} \mathrm{mL}^{-1}$; for naphthalene between $0.008 \mu \mathrm{g} \mathrm{mL}^{-1}$ and $0.4 \mu \mathrm{g} \mathrm{mL} \mathrm{L}^{-1}$; for benzo(a)anthracene, crysene, benzo(b)fluoranthene and benzo(k)fluoranthene between $0.008 \mu \mathrm{g} \mathrm{mL}{ }^{-1}$ and $0.6 \mu \mathrm{gL}^{-1}$; and for benzo(a)pyrene, indeno(1,2,3-c,d)pyrene, dibenzo(a,h)anthracene and benzo(g,h,i)perylene between $0.025 \mu \mathrm{g} \mathrm{mL}^{-1}$ and $0.6 \mu \mathrm{gL}^{-1}$.

\section{Standards and reagents}

A standard solution obtained from ChemService (West Chester, PA, USA) was used, prepared in dichloromethane: benzene $(50: 50, \mathrm{v} / \mathrm{v})$ and containing $2.000 \mu \mathrm{g} \mathrm{mL}^{-1}$ of each PAH studied, that is, naphthalene, acenaphthalene, acenaphtene, fluorene, phenanthrene, anthracene, fluoranthene, pyrene, benzo(a)anthracene, chrysene, benzo(b)fluoranthene, benzo(k)fluoranthene, benzo(a)pyrene, dibenzo(a,h)anthracene, benzo(ghi)perylene and indeno(1,2,3-c,d)pyrene. Dichloromethane and $n$-hexane (pesticide residual degree) were obtained from Tedia Company Inc.; anhydrous sodium sulfate from J.T. Baker; and alumina (80-200mesh) from Fisher Scientific.

\section{PAH extraction and clean-up}

$10 \mathrm{~g}$ of dry soil or SS sample were transferred to $250 \mathrm{~mL}$-centrifuge tubes; $20 \mathrm{~mL}$ of dichloromethane (DCM) was added and the sample was shaken in a sonic shaker for $30 \mathrm{~min}$, centrifuged and the organic supernatant was preserved; this procedure was repeated with $20 \mathrm{~mL}$ of $n$-hexane; the collected organic extract was submitted to evaporation to reduce the volume to $3 \mathrm{~mL}$ using a Syncore Analyst from Buchi. For the clean-up procedure, the soil or SS-extract was transferred to $1.5 \mathrm{~cm}$ diameter glass column containing $2 \mathrm{~g}$ of alumina (activated $\mathrm{Al}_{2} \mathrm{O}_{3}$ ) and $1.0 \mathrm{~g}$ of anhydrous sodium sulfate $\left(\mathrm{Na}_{2} \mathrm{SO}_{4}\right)$ The PAHs were eluted with $10 \mathrm{~mL}$ of $n$-hexane: DCM $(19: 1, \mathrm{v} / \mathrm{v})$, and after, with $15 \mathrm{~mL}$ of $n$-hexane: DCM $(1: 2, \mathrm{v} / \mathrm{v}) .{ }^{30}$ All the percolate was collected and evaporated to reduce the volume to $1 \mathrm{~mL}$.

\section{PAH quantification and validation of methods}

The method of external standardization was used for the PAH quantification. Standard stock solutions containing $80 \mathrm{mg} \mathrm{L}^{-1}$ of each PAH were prepared in dichloromethane. And these stock solutions were diluted to prepare the standard solutions $\left(1.0 \mathrm{mg} \mathrm{L}^{-1}\right)$ also in dichloromethane. Afterwards, the work solutions were prepared by means of successive dilutions in $n$-hexane and they were used to determine the detector linearity, fortify samples and obtain the standard analytical curves.

Samples from the soil control treatment were submitted to extraction procedures in three different days and duplicated for each fortification level. For the recovery step, the soil samples without SS-addition were fortified with $10 \mu \mathrm{g} \mathrm{kg}^{-1}, 20 \mu \mathrm{g} \mathrm{kg}^{-1}$ and $50 \mu \mathrm{g} \mathrm{kg}^{-1}$ of a mixture of the sixteen PAHs in order to evaluate the method accuracy (recovery) and precision (repetitiveness and intermediary precision).

\section{Sample analysis by ion trap GC-MS}

Sixteen PAHs were analyzed using a gas chromatograph model 3900 - coupled to an ion trap mass spectrometer model Saturno 2100T, both from Varian, and a Restek capillary column $\left(\mathrm{RTX}^{\circledR}-5\right.$ Sil MS, $30 \mathrm{~m} \times 0.25 \mathrm{~mm}$ i.d. $\times$ $0.25 \mu \mathrm{m})$. A constant flow rate at $1.0 \mathrm{~mL} \mathrm{~min}^{-1}$ of helium was used as a carrier gas. The trap, manifold, transfer-line and injector temperature were $220^{\circ} \mathrm{C}, 60^{\circ} \mathrm{C}, 280^{\circ} \mathrm{C}$ and $250^{\circ} \mathrm{C}$, 
respectively. The oven temperature was initially $50^{\circ} \mathrm{C}$ per $1 \mathrm{~min} ; 10^{\circ} \mathrm{C}$ min $^{-1}$ until $150^{\circ} \mathrm{C}$ per $2 \mathrm{~min} ; 6^{\circ} \mathrm{C}$ min $^{-1}$ until $220^{\circ} \mathrm{C} ; 4^{\circ} \mathrm{C} \min ^{-1}$ until $286^{\circ} \mathrm{C}$ and $10^{\circ} \mathrm{C} \mathrm{min}^{-1}$ until $300^{\circ} \mathrm{C}$. The injection volume was $1 \mu \mathrm{L}$ and injection was pulsedsplitless mode with 25 psi during $1.10 \mathrm{~min}$. The acquisition data was obtained in the MS/MS mode, using electron impact ionization voltage of $70 \mathrm{eV}$ and emission current of $20 \mu \mathrm{A}$. The method was developed using Automatic Method Developed (AMD) where the collision induced dissociation (CID), waveform and other conditions were selected for all PAHs (Table S1, see Supplemantary Information)

\section{Precision and accuracy}

The original control soil- and SS-samples were submitted to the extraction procedures in three different days and in duplicated fortification levels $\left(10 \mu \mathrm{g} \mathrm{kg}^{-1}\right.$, $20 \mu \mathrm{g} \mathrm{kg}^{-1}$ and $50 \mu \mathrm{g} \mathrm{kg}^{-1}$ of a mixture of the sixteen $\mathrm{PAHs})$. The results were satisfactory as concerned to the method accuracy (recovery) and precision. For most PAH compounds, accuracy and precision were within the range of $70-120 \%$ with coefficient of variation lower than $20 \%$. The same method of PAH determination was used for soil and sewage sludge samples.

\section{Results and Discussion}

\section{PAH residue levels in soil samples}

The analysis results of sixteen different PAHs (median, minimum and maximum PAH residue concentrations) in fifty four dried soil samples (eighteen samples from each treatment - STEST, SDL1N and SDL8N plots) from field plots cultivated with maize are presented in Tables S2-S4. The detection occurrences indicate whether PAH was detected and quantified in at least one sample (d.q.), PAH was detected in at least one sample but not quantified in any sample (d.n.q.), and PAH was not detected in any sample (n.d.).

\section{Sewage sludge PAH concentrations}

The analysis results of sixteen PAHs in six SS samples (from Franca City - State of São Paulo) used in this experiment are presented in Table S5. It is important to highlight that several PAHs were reported to be also found in SS samples from the sanitation plants of Barueri and Suzano Cities, both of the State of São Paulo. ${ }^{13}$

The PAH residue concentration values and detection classes showed significant differences between the median and maximum PAH residue values in soil samples from
STEST, SDL1N and SDL8N plots. The total sum of maximum PAH residues in the soil samples allowed ranking the plots as follows: SDL8N > SDL1N > STEST. The results evidenced a clear relation between the increasing PAH rate applied to the soil and the increasing total soil PAH residue concentration. And also that the total sum of median, mean or maximum PAH values in the original SS will determine the PAH concentration levels in the SDL1N and SDL8N plots treated with $28.15 \mathrm{t} \mathrm{ha}^{-1}$ and $225.2 \mathrm{tha}^{-1}$, respectively.

It was observed that all PAHs were detected or quantified in the soil samples from SDL1N and SDL8N plots, meanwhile among those from the control plots (STEST) the lowest number of detected or quantified PAHs were found. The results evidenced that the use of SS as agricultural fertilizer may contaminate soils with PAHs, as also observed by Oleszczuk and Baran. ${ }^{19}$ The total load of SS-PAHs disposed in the SS-treated plots and the PAH physical-chemical characteristics such as soil sorption and half-life (Table 1) are the main causes of soil contamination risk.

High mean and median phenanthrene values were found in the SS samples compared to the other PAH residue values in the same sludge material. The phenanthrene (light $\mathrm{PAH}$ ) characteristics such as low lipid affinity, relatively high water solubility and high vapor pressure favor its preferential uptake by plants, in this case maize plants, and its transport to grains. ${ }^{19,25}$ In this research, the SS analysis revealed $67 \%$ of PAHs with two, three or four aromatic rings (light PAHs) and 33\% with five or six aromatic rings (heavy PAHs). Sewage sludge PAH and other compound contents may be seasonal dependent, and retention and bioavailability in soil samples depend on sorption, water solubility, and charged functional groups in the molecules. ${ }^{17}$

According to Haynes et al., ${ }^{31}$ sewage sludge application to lands will inevitably elevate soil PAH concentrations. It is thought that PAHs bind strongly to SS-organic matter what initially limits their decomposition. However, as the SS-organic matter begins to breakdown, the sorptive processes are weakened and PAH degradation proceeds. During decomposition, there is a rapid disappearance of low molecular mass PAHs and a slower degradation of higher molecular mass compounds.

After cessation of SS applications on two long-term monitoring fields, Beck et al. ${ }^{32}$ observed $90 \%$ loss of total soil PAHs from one field and about $65 \%$ from the other. Half-lives ranged from 2 years for naphthalene to over 7 years for fluoranthene, and over 9 years for benzol[ghi] perylene and coronene. PAH-degradation was faster under tilled cropping (which enhances organic matter decomposition) than under no-till or undisturbed soils (pasture, trees). ${ }^{15,33}$ 
Petrogenic PAHs are mainly constituted by two or three aromatic rings, meanwhile PAHs originated from organic matter combustion present higher relative frequency of compounds with four to six rings. According to Budzinski et al. ${ }^{34}$ the quotient between phenanthrene and anthracene concentrations in a same matrix, allow identifying the PAH origin. The high predominance of thermodynamically stable phenanthrene on its isomer anthracene is characteristic of contamination by petroleum products. ${ }^{35}$ These authors affirm that a quotient of [phenanthrene]/[anthracene] > 15 indicates the presence of petrogenic PAHs, that is, PAHs originated from petroleum; or, a quotient of [phenanthrene]/[anthracene] $<10$ indicates the presence of PAHs from organic matter pyrolysis. Several other studies reported in the literature have suggested the quotient between two particular PAHs may reveal the matrix PAH origin. ${ }^{36-38}$ According to these criteria, the average values of phenanthrene and anthracene found in the present work indicated that SS-PAH are of petrogenic origin. Another ratio, using Antracene/(Anthracene+Phenanthrene), reinforce the origin of these PAHs, since the obtained value was 0.06 and values lower than 0.1 indicate the presence of petrogenic PHA. ${ }^{37}$ This result suggests that the sewage sludge used in this study received significant contribution of wastewaters from gas stations, auto repair shops, truck or city bus garages and car dealer shops.

\section{Risk simulation of soil contamination by PAHs from sewage sludges}

The physical-chemical properties of PAHs (Table 1), the PAH concentration levels in the soil samples from STEST, SDL1N and SDL8N plots, the soil attributes and the sewage sludge PAH concentrations allowed simulating the risk of soil contamination by PAH from continuous SS application to the soil as plant fertilizers.

It is supposed $t_{0}$ (days) is the time interval between two consecutive SS applications to an agricultural soil and soil PAH degradation is described by a first order kinetic equation with constant degradation rates for each PAH.

It was adopted the notation $\mathrm{C}_{\mathrm{i}-1}^{\mathrm{PAH}}\left(\mu \mathrm{g} \mathrm{kg}^{-1}\right)$ for the soil PAH concentration in the beginning of the $\mathrm{i}^{\text {th }}$ time interval $\left(1^{\text {st }}\right.$ interval $\left.=\mathrm{C}_{0}^{\mathrm{PAH}}, 2^{\text {nd }}=\mathrm{C}_{1}^{\mathrm{PAH}}, 3^{\text {rd }}=\mathrm{C}_{2}^{\mathrm{PAH}}, \ldots\right)$ and it was assumed equal to $\mathrm{t}_{0}$ all the intervals between two consecutive applications.

As $\mathrm{C}_{0}^{\mathrm{PAH}}$ is the initial soil PAH concentration after the first SS application, thus, at the end of the first $t_{0}$ interval or beginning of the second SS application the $\mathrm{C}_{0}^{\mathrm{PAH}}$ concentration will be degraded to $\mathrm{C}_{0}^{\mathrm{PAH}} \mathrm{e}^{-\mathrm{kt}_{0}}$ and it will be added to the second application resulting as $\mathrm{C}_{0}^{\mathrm{PAH}}+\mathrm{C}_{0}^{\mathrm{PAH}} \mathrm{e}^{-\mathrm{kt}_{\mathrm{t}}}$. Therefore, in the beginning of the $\mathrm{n}^{\text {th }}$ interval or the $\mathrm{n}^{\text {th }}$ SS application, the soil PAH concentration can be estimated by

$$
\begin{aligned}
\mathrm{C}_{\mathrm{n}}^{\mathrm{PAH}}=\mathrm{C}_{0}^{\mathrm{PAH}}+\mathrm{C}_{0}^{\mathrm{PAH}} \mathrm{e}^{-\mathrm{kt}_{0}}+\mathrm{C}_{0}^{\mathrm{PAH}} \mathrm{e}^{-2 \mathrm{kt}_{0}}+\ldots+\mathrm{C}_{0}^{\mathrm{PAH}} \mathrm{e}^{-(\mathrm{n}-1) \mathrm{kt}_{0}}= \\
\\
=\mathrm{C}_{0}^{\mathrm{PAH}}+\mathrm{C}_{0}^{\mathrm{PAH}} \mathrm{e}^{-\mathrm{kt}_{0}}\left[\left(1-\mathrm{e}^{-\mathrm{nkt}_{0}}\right) /\left(1-\mathrm{e}^{-\mathrm{kt}_{0}}\right)\right]
\end{aligned}
$$

Consequently, the limit soil PAH concentration can be simulated by

$\mathrm{C}_{\infty}^{\mathrm{PAH}}=\lim _{\mathrm{n} \rightarrow \infty} \mathrm{C}_{\mathrm{n}}^{\mathrm{PAH}}=\mathrm{C}_{0}^{\mathrm{PAH}}+\mathrm{C}_{0}^{\mathrm{PAH}} /\left(\mathrm{e}^{-\mathrm{kt}_{0}}-1\right)$

where, $\mathrm{k}\left(\mathrm{day}^{-1}\right)$ is the soil PAH degradation rate calculated as $\mathrm{k}=0.693 / \mathrm{t}_{1 / 2}$, and $\mathrm{t}_{1 / 2}$ is the PAH half-life in the soil. ${ }^{39}$

Since there is always increasing soil PAH concentrations in consequence of the successive equal SS rates yearly applied, than $\mathrm{C}_{0}^{\mathrm{PAH}}<\mathrm{C}_{1}^{\mathrm{PAH}}<\mathrm{C}_{2}^{\mathrm{PAH}}<\ldots<\mathrm{C}_{\mathrm{n}}^{\mathrm{PAH}}<\ldots<\mathrm{C}_{\infty}^{\mathrm{PAH}}$.

It is important to observe that the soil PAH limit concentration depends directly on the SS-PAH concentration that will define the soil PAH initial concentration, and, inversely on the soil PAH degradation rate.

The initial PAH concentration in a humid soil basis, $\mathrm{C}_{0}^{\mathrm{PAH}}\left(\mu \mathrm{g} \mathrm{kg}^{-1}\right)$, was estimated by $\mathrm{C}_{0}^{\mathrm{PAH}}=\rho_{\mathrm{Sd}} \mathrm{K}_{\mathrm{D}} \mathrm{C}_{\mathrm{w} 0}^{\mathrm{PAH}} / \rho_{\mathrm{Sw}}$, where $\mathrm{C}_{\mathrm{w0}}^{\mathrm{PAH}}\left(\mu \mathrm{g} \mathrm{\textrm {L } ^ { - 1 } )}\right.$ is the soil solution initial concentration and $\rho_{\mathrm{Sd}}\left(\mathrm{kg} \mathrm{L}^{-1}\right)$ and $\rho_{\mathrm{Sw}}\left(\mathrm{kg} \mathrm{L}^{-1}\right)$ are the soil density in a dry and humid basis, respectively; and $\mathrm{K}_{\mathrm{D}}\left(\mathrm{L} \mathrm{kg}^{-1}\right)$ is the soil PAH distribution coefficient, calculated by $\mathrm{K}_{\mathrm{D}}=\mathrm{f}_{\mathrm{OC}} \mathrm{K}_{\mathrm{OC}}$ where $\mathrm{f}_{\mathrm{OC}}$ is the soil organic carbon volumetric fraction and $\mathrm{K}_{\mathrm{OC}}$ $\left(\mathrm{L} \mathrm{kg}^{-1}\right)$ is the PAH sorption coefficient in the soil organic carbon. The soil solution initial concentration, $C_{\mathrm{w} 0}^{\mathrm{PAH}}\left(\mu \mathrm{g} \mathrm{L}^{-1}\right)$, was estimated by $\mathrm{C}_{\mathrm{w} 0}^{\mathrm{PAH}}=\left(\mathrm{C}_{\mathrm{SS}}^{\mathrm{PAH}} \times \mathrm{d} \times 10^{-7}\right) / \varepsilon\left(\rho_{\mathrm{Sd}} \mathrm{K}_{\mathrm{D}}^{\mathrm{PAH}}+\theta+\right.$ $\left.\delta K_{\mathrm{AW}}^{\mathrm{PAH}}\right)$, where $\mathrm{C}_{\mathrm{SS}}^{\mathrm{PAH}}\left(\mu \mathrm{gg}^{-1}\right)$ is SS-PAH concentration in a dry basis, $\mathrm{d}\left(\mathrm{t} \mathrm{ha}^{-1}\right)$ is the SS-rate in a humid basis applied to the soil, $\varepsilon(\mathrm{m})$ is the average soil depth of SS-PAH initial concentration dissipation, $\theta$ is the soil water volumetric content at field capacity, $\delta$ is the soil air volumetric content (porosity), $\mathrm{K}_{\mathrm{AW}}$ is the PAH air/water partition coefficient estimated by $\mathrm{K}_{\mathrm{AW}}=\left(\mathrm{V}_{\mathrm{p}} \times \mathrm{M}_{\mathrm{w}}\right) /\left(\mathrm{W}_{\mathrm{s}} \times \mathrm{R} \times \mathrm{T}\right)$, where $\mathrm{R}=8.314 \mathrm{~kJ} \mathrm{~mol}^{-1} \mathrm{~K}^{-1}$ is the gas constant, $\mathrm{T}=298 \mathrm{~K}$ is the room temperature in Kelvin and $\mathrm{V}_{\mathrm{p}}(\mathrm{Pa}), \mathrm{M}_{\mathrm{w}}\left(\mathrm{g} \mathrm{mol}^{-1}\right)$ and $\mathrm{W}_{\mathrm{s}}\left(\mathrm{g} \mathrm{mol}^{-1}\right)$ are the PAH vapor pressure, molar mass and water solubility values, respectively. ${ }^{40}$

The PAH physicochemical properties required to estimate the soil solution and soil PAH initial concentrations are shown in Table 1, and the simulated soil PAH concentrations ten years after hypothetic SS applications and soil PAH limit concentrations are shown in Table S6.

For the simulation test of soil contamination risk by SS-PAHs, data on average soil PAH concentrations from SDL1N plots that have been yearly treated with SS since 1999 before maize cropping were used (experimental fields 
of Embrapa Environment). It was supposed that the SS continuously used in the experimental SDL1N plots had the same characteristics and average composition of the SS presented in Table 6; similarly, the simulated SS rates were assumed to be equal to the SS rates applied to SDL1N plots $\left(28.15 \mathrm{t} \mathrm{ha}^{-1}\right)$; and, in the same way, it was assumed $10.0 \mathrm{~cm}$ average soil depth for the initial PAH concentration dissipation and $1.1 \mathrm{t} \mathrm{m}^{-3}$ density for the humid SS. And, the following equations were required: (i) equations to estimate the PAH initial concentrations; (ii) equations to estimate the $\mathrm{n}^{\text {th }}$ PAH soil concentration; and (iii) equations to estimate each PAH soil concentration limit. The simulation results of (i), (ii) and (iii) plus the total PAH concentration in the soil, are presented in Table S6.

The data was used to simulate the contamination risk and to indicate the most wanted SS- PAHs to be monitored in soil quality monitoring programs involving continuously SS-fertilized soils. The simulation resulted in the following PAH classification, ranked in a decreasing degree of contamination risk: phenanthrene $>$ chrysene $>$ benzo(k)fluoranthene $>$ benzo(a)pyrene $>$ pyrene $>$ benzo(b)fluoranthene $>$ benzo(g,h,i)perylene $>$ indeno(1,2,3-c,d)pyrene $>$ fluoranthene $>$ benzo(a)anthracene $>$ dibenzo $(\mathrm{a}, \mathrm{h})$ anthracene $>$ fluorene $>$ anthracene $>$ naphthalene $>$ acenaphthene $>$ acenaphthylene. This classification agrees with the dependent relationship between the soil limit concentration and the soil initial concentration, calculated from the average $\mathrm{PAH}$ concentration values in the sewage sludge and the PAH half-lives in the soil (Table 1).

The simulated PAH concentrations values after ten years of successive SS applications compared to the median and maximum values determined in soil samples from the SDL1N plots evidenced consistence of results, since the compared values showed the same order of magnitude. And most determined median concentrations were lower than the simulated ones. The observed soil concentrations that showed higher values than the simulated limit concentrations were attributed to the SS origin, to the sequential rates applied to the plots and to the fact that the PAH degradation rate decreases as soil PAH concentration increases. ${ }^{19}$

The simulation results presented in Table S6 were obtained supposing constant degradation rates, once an equation expressing a relationship between $\mathrm{PAH}$ degradation rate in soils and soil PAH concentrations was not available in the literature. Therefore, the approach used in this research work is conservative, because the PAH persistence in soil increases with the increasing soil PAH concentrations. ${ }^{19}$

It is important to highlight that PAH properties such half-life in soil $\left(\mathrm{t}_{1 / 2}\right)$, soil distribution coefficient $\left(\mathrm{K}_{\mathrm{D}}\right)$ and concentration in sewage sludge $\left(\mathrm{C}_{\mathrm{SS}}^{\mathrm{PAH}}\right)$ are determinant factors for an actual soil contamination risk by PAHs.
The simulated limit soil concentrations indicate that soils from experimental fields of Embrapa-Environment are hypothetically at the maximum capacity to hold SS-PAHs, because the observed values $\mathrm{C}_{10}^{\mathrm{PAH}}$ are very close to the simulated ones $\mathrm{C}_{\infty}^{\mathrm{PAH}}$, evidencing that $\mathrm{PAH}$ concentration levels found in sewage sludges might raise potential contamination risks to the soil.

\section{Conclusions}

The presence of polycyclic aromatic hydrocarbons (PAHs) [acenaphthene, acenaphthylene, anthracene, benzo(a)anthracene, benzo(a)pyrene, benzo(b) fluoranthene, benzo(g,h,i)perylene, benzo(k)fluoranthene, chrysene, dibenzo(a,h)anthracene, fluoranthene, fluorene, indeno(1,2,3-c,d)pyrene, naphthalene, phenanthrene and pyrene] were experimentally observed in sewage sludge samples and its continuous use as fertilizer might contaminate soils with PAHs. The soil PAH concentration simulations indicated the priority order of wanted PAHs for a soil quality monitoring program: phenanthrene $>$ chrysene $>$ benzo(k)fluoranthene $>$ benzo(a)pyrene $>$ pyrene $>$ benzo(b)fluoranthene $>$ benzo(g,h,i)perylene $>$ indeno(1,2,3-c,d)pyrene $>$ fluoranthene $>$ benzo(a)anthracene $>$ dibenzo(a,h)anthracene $>$ fluorene $>$ anthracene $>$ naphthalene $>$ acenaphthene $>$ acenaphthylene. The soil PAH concentrations were positively correlated to the sewage sludge PAH concentrations and to the sewage sludge rates applied to the soil. The PAH concentration levels found in sewage sludges might raise potential contamination risks to the soil. Therefore, additional research on this subject is of high concern and priority in order to achieve an ecologically correct and sustainable agriculture. More research is needed to better know the PAH and persistent organic pollutants (POPs) concentration range in sewage sludges of varied origins and the consequent ecosystem impact before using them as fertilizers in agriculture.

\section{Acknowledgments}

The authors thank Marley M. Tavares for the sample preparation. Financial support for this research was provided by Embrapa (Empresa Brasileira de Pesquisa Agropecuária) grant number MP3/03065100001 and Fapesp (Fundação de Amparo à Pesquisa do Estado de São Paulo) grant number 2007/04427-8.

\section{Supplementary Information}

Supplementary information is available free of charge at http://jbcs.sbq.org.br as a PDF file. 


\section{References}

1. US-EPA; Provisional Guidance for Qualitative Risk Assessment of Polycyclic Aromatic Hydrocarbons, U.S. Environmental Protection Agency. Office of Research and Development: Washington, DC, 1993. (EPA/600/R-93/089).

2. http://monographs.iarc.fr/ENG/Monographs/vol32/volume32. pdf accessed in June 2010.

3. Fismes, J.; Perrin-Ganier, C.; Empereur-Bissonnet, P.; Morel, J. L.; J. Environ. Qual. 2002, 31, 1649.

4. Camargo, M. C. R.; Toledo, M. C. F.; Braz. J. Food Technol. 2002, 5, 19.

5. Zohair, A.; Salim, A.B.; Soyibo, A. A.; Beck, A. J.; Chemosphere 2006, 63, 541 .

6. Farhadian, A.; Jinap, S.; Faridah, A.; Sakar, Z. I.; Food Control 2010, 21, 606.

7. Kulhánek, A.; Trapp, S.; Sismilich, M.; Jank , J.; Zimová, M.; Sci. Total Environ. 2005, 339, 71.

8. Collins, C.; Fryer, M.; Grosso, A.; Environ. Sci. Technol. 2006, $40,45$.

9. Chouychai, W.; Thongkukiatkul, A.; Upatham, S.; Lee, H.; Pokethitiyook, P.; Kruatrachue, M.; Environ. Toxicol. 2007, 22, 597.

10. Paraíba, L. C.; Queiroz, S. C. N.; Maia, A. de H. N.; Ferracini, V. L.; Sci. Total Environ. 2010, 408, 3270.

11. Fernandes, S. A. P.; Bettiol, W.; Cerri, C. C.; Camargo, P.; Geoderma 2005, 125, 49.

12. Fernandes, S. A. P.; Bettiol, W.; Cerri, C. C.; Appl. Soil Ecol. 2005, 30, 65 .

13. Tsutiya, M. T.; Comparini, J. B.; Sobrinho, A. P.; Hespanol, I.; de Carvalho, P. C. T.; Melfi, A. J.; Biossólidos na Agricultura, Sabesp: São Paulo, Brasil, 2001.

14. Alcantara, S.; Pérez, D. V.; Almeida, M. R. A.; Silva, G. M.; Polidoro, J. C.; Bettiol, W.; Water, Air, Soil Pollut. 2009, 203, 3.

15. Oleszczuk, P.; Chemosphere 2006, 65, 1616.

16. Mantovi, P.; Baldoni, G.; Toderi, G.; Water Res. 2005, 39, 289.

17. Kinney, C. A.; Furlong, E. T.; Zaugg, S. D.; Burkhardt, M. R.; Werner, S. L.; Cahill, J. D.; Jorgensen, G. R.; Environ. Sci. Technol. 2006, 40, 7207.

18. ftp://ftp.sp.gov.br/ftpcomitepcj/Res-CONAMA-375-06.PDF accessed in June 2010.

19. Oleszczuk, P; Baran, S.; Water, Air, Soil Pollut. 2005, 168, 91.

20. Jones, K. C.; Stratford, J. A.; Tidridge, P.; Waterhouse, K. S.; Johnston, A. E.; Environ. Pollut. 1989, 56, 337.
21. Tao, S.; Jiao, X. C.; Chen, S. H; Liu, W. X.; Coveney Jr, R. M.; Zhu, L. Z; Luo, Y. M.; Environ. Pollut. 2006, 140, 406.

22. http://www.cetesb.sp.gov.br accessed in June 2010.

23. Dreher, P.; Contaminants in Arable Soils in Baden-Wurttemberg Fertilized with Sewage Sludge - Concise Report; Landesanstalt fur Umweltschutz (State Institute for Environmental Protection): Baden-Wurttemberg, 2003, Vol.16.

24. http://njaes.rutgers.edu/pubs/publication.asp?pid=FS957 accessed in June 2010.

25. Paraíba, L. C.; Saito, M. L.; Pesq. Agropec. Bras. 2005, 40, 853.

26. Dynia, J. F.; De Souza, M. D.; Boeira, R. C.; Pesq. Agropec. Bras. 2006, $41,855$.

27. http://www.syrres.com/what-we-do/databaseforms. aspx id=386 accessed in June 2010.

28. Howard, P. H.; Boethling, R. S.; Jarvis, W. F.; Meylan, W. M.; Michalenko, E. M.; Handbook of Environmental Degradation Rates, Lewis Publishers: Chelsea, 1991.

29. Chiou, C.T.; Environ. Sci. Technol. 1985, 19, 57.

30. Pérez, S.; Guillamón, M.; Barceló, D; J. Chromatogr., A 2001, 938, 57.

31. Haynes, R. J.; Murtaza, G.; Naidu, R.; Adv. Agron. 2009, 104, 165.

32. Beck, A. J.; Johnson, D. L.; Jones, K. C.; Sci. Total Environ. 1996, 185, 125.

33. Saison, C.; Perrin-Ganier, C.; Schiavon, M.; Morel, J. L.; Environ. Pollut. 2004, 130, 275.

34. Budzinski, H.; Jones, I.; Bellocq, J.; Piérard, C.; Garrigues, P.; Mar. Chem. 1997, 58, 85.

35. Baumard, P.; Budzinski, H.; Michona, Q.; Garrigues, P.; Burgeot, T.; Bellocq, J; Estuar. Coast. Shelf Sci. 1998, 47, 77.

36. Soclo, H. H.; Garrides, P. H.; Ewald, M.; Mar. Pollut. Bull. 2000, 40, 387.

37. Maioli, O. L. G.; Rodrigues, K. C.; Knoppers, B. A.; Azevedo, D. A.; J. Braz. Chem. Soc. 2010, 21, 1543.

38. Froehner, S.; Maceno, M.; da Luz, E. C.; Souza, D. B.; Machado, K. S.; Environ. Monit. Assess. 2010, 168, 205.

39. Aguiar, A. F. A.; Xavier, A. F. S.; Rodrigues, J. E. M.; Cálculo para Ciências Médicas e Biológicas, Editora Harbra Ltda.: São Paulo, Brasil, 1988, p. 216.

40. Trapp, S.; Matthies, M.; Chemodynamics and Environmental Modeling, Springer: Heidelberg, 1998.

Submitted: June 14, 2010

Published online: February 22, 2011

FAPESP has sponsored the publication of this article. 


\title{
Risk Simulation of Soil Contamination by Polycyclic Aromatic Hydrocarbons from Sewage Sludge used as Fertilizers
}

\author{
Lourival C. Paraíba, Sonia C. N. Queiroz,* Débora R. C. de Souza and Maria L. Saito \\ Embrapa Meio Ambiente, Rodovia SP 340, km 127,5, Tanquinho Velho, CP 69, \\ 13820-000 Jaguariúna-SP, Brazil
}

Table S1. Conditions for the GC-EI-MS-MS analysis of PAHs

\begin{tabular}{|c|c|c|c|c|c|}
\hline PAHs compounds & Retention time / min & Parent ion / $(\mathrm{m} / \mathrm{z})$ & Wave-form type & $\operatorname{ESL} /(m / z)$ & CID amplitude / V \\
\hline naphthalene & 9.14 & 128 & Resonant & 56 & 0.6 \\
\hline acenaphthylene & 13.3 & 152 & Resonant & 48 & 0.2 \\
\hline acenaphthene & 13.9 & 153 & Resonant & 67 & 0.2 \\
\hline fluorene & 15.9 & 165 & Resonant & 73 & 0.2 \\
\hline phenanthrene & 19.6 & 178 & Resonant & 78 & 0.2 \\
\hline anthracene & 19.8 & 178 & Resonant & 78 & 0.2 \\
\hline fluoranthene & 24.3 & 202 & Resonant & 89 & 0.2 \\
\hline pyrene & 25.2 & 202 & Resonant & 89 & 0.2 \\
\hline benzo(a)anthracene & 30.7 & 228 & Resonant & 101 & 0.2 \\
\hline chrysene & 30.8 & 228 & Resonant & 101 & 0.2 \\
\hline benzo(b)fluoranthene & 35.8 & 252 & Resonant & 111 & 0.2 \\
\hline benzo(k)fluoranthene & 36.0 & 252 & Resonant & 111 & 0.2 \\
\hline benzo(a)pyrene & 37.2 & 252 & Resonant & 111 & 0.2 \\
\hline indeno(1,2,3-c,d)pyrene & 42.0 & 276 & Resonant & 122 & 0.6 \\
\hline dibenzo(a,h)anthracene & 42.2 & 276 & Resonant & 122 & 0.6 \\
\hline benzo(g,h,i)perylene & 42.9 & 276 & Resonant & 122 & 0.6 \\
\hline
\end{tabular}

$\mathrm{ESL}=$ excitation storage level. $\mathrm{CID}=$ collision induced dissociation. 
Table S2. Polycyclic aromatic hydrocarbon (PAH) median, minimum and maximum concentrations in soil samples from the control plots $(\mathrm{STEST})$, $(\mathrm{n}=18)$

\begin{tabular}{|c|c|c|c|c|}
\hline PAHs & Median / $\left(\mu \mathrm{g} \mathrm{kg}^{-1}\right)$ & Minimum / $\left(\mu \mathrm{g} \mathrm{kg}^{-1}\right)$ & Maximum / $\left(\mu \mathrm{g} \mathrm{kg}^{-1}\right)$ & Occurence \\
\hline naphthalene & $<\mathrm{LOQ}$ & $<$ LOD & 6.3 & d.q. \\
\hline acenaphthylene & $<\mathrm{LOD}$ & $<$ LOD & $<$ LOD & n.d. \\
\hline acenaphthene & $<\mathrm{LOD}$ & $<$ LOD & 1.3 & d.q. \\
\hline fluorene & $<\mathrm{LOQ}$ & $<$ LOD & 1.8 & d.q. \\
\hline phenanthrene & 1.0 & $<$ LOD & 3.7 & d.q. \\
\hline anthracene & $<\mathrm{LOQ}$ & $<$ LOD & 1.3 & d.q. \\
\hline fluoranthene & $<\mathrm{LOQ}$ & $<$ LOD & 1.9 & d.q. \\
\hline pyrene & $<$ LOD & $<$ LOD & 1.5 & d.q. \\
\hline benzo(a)anthracene & $<\mathrm{LOQ}$ & $<$ LOD & 3.0 & d.q. \\
\hline chrysene & $<\mathrm{LOQ}$ & $<$ LOD & 2.3 & d.q. \\
\hline benzo(b)fluoranthene & $<\mathrm{LOQ}$ & $<$ LOD & $<\mathrm{LOQ}$ & d.n.q. \\
\hline benzo(k)fluoranthene & $<$ LOD & $<$ LOD & $<\mathrm{LOQ}$ & d.n.q. \\
\hline benzo(a)pyrene & $<$ LOD & $<$ LOD & $<$ LOD & n.d. \\
\hline indeno $(1,2,3-\mathrm{c}, \mathrm{d})$ pyrene & $<\mathrm{LOD}$ & $<$ LOD & 4.5 & d.q. \\
\hline dibenzo(a,h)anthracene & $<$ LOD & $<$ LOD & $<\mathrm{LOQ}$ & d.n.q. \\
\hline benzo $(\mathrm{g}, \mathrm{h}, \mathrm{i})$ perylene & $<$ LOD & $<$ LOD & $<\mathrm{LOD}$ & n.d. \\
\hline
\end{tabular}

LOD = limit of detection; $\mathrm{LOQ}=$ limit of quantification; d.q. = detected and quantified; d.n.q. = detected and not quantified; n.d. = not detected.

Table S3. Polycyclic aromatic hydrocarbon (PAH) median, minimum and maximum concentrations in soil samples from the sewage sludge (SS) treated plots (SDL1N), $\mathrm{n}=18$

\begin{tabular}{|c|c|c|c|c|}
\hline PAHs & Median / $\left(\mu \mathrm{g} \mathrm{kg}^{-1}\right)$ & Minimum / $\left(\mu \mathrm{g} \mathrm{kg}^{-1}\right)$ & Maximum / $\left(\mu \mathrm{g} \mathrm{kg}^{-1}\right)$ & Occurence \\
\hline naphthalene & $<$ LOQ & $<$ LOQ & 3.27 & d.q. \\
\hline acenaphthylene & $<$ LOD & $<$ LOD & $<\mathrm{LOQ}$ & d.n.q. \\
\hline acenaphthene & $<$ LOQ & $<$ LOD & 1.66 & d.q. \\
\hline fluorene & $<$ LOQ & $<$ LOD & 1.54 & d.q. \\
\hline phenanthrene & 1.6 & $<$ LOD & 2.74 & d.q. \\
\hline anthracene & $<$ LOQ & $<$ LOD & 2.04 & d.q. \\
\hline fluoranthene & 0.76 & $<$ LOD & 2.81 & d.q. \\
\hline pyrene & $<$ LOD & $<$ LOD & 2.63 & d.q. \\
\hline benzo(a)anthracene & $<$ LOQ & $<$ LOD & 3.32 & d.q. \\
\hline chrysene & 1.6 & $<$ LOD & 4.47 & d.q. \\
\hline benzo(b)fluoranthene & $<\mathrm{LOQ}$ & $<$ LOD & 6.45 & d.q. \\
\hline benzo(k)fluoranthene & $<$ LOD & $<$ LOD & $<\mathrm{LOQ}$ & d.n.q. \\
\hline benzo(a)pyrene & $<\mathrm{LOD}$ & $<\mathrm{LOD}$ & $<\mathrm{LOQ}$ & d.n.q. \\
\hline indeno( $(1,2,3-c, d)$ pyrene & $<$ LOD & $<$ LOD & 5.52 & d.q. \\
\hline dibenzo(a,h)anthracene & $<$ LOD & $<$ LOD & 3.26 & d.q. \\
\hline benzo(g,h,i)perylene & $<$ LOD & $<\mathrm{LOD}$ & 3.34 & d.q. \\
\hline
\end{tabular}

$\mathrm{LOD}=$ limit of detection; $\mathrm{LOQ}=$ limit of quantification; d.q. = detected and quantified; d.n.q. = detected and not quantified; n.d. = not detected. 
Table S4. Polycyclic aromatic hydrocarbon (PAH) median, minimum and maximum concentrations in soil samples from the sewage sludge (SS) treated plots (SDL8N), $\mathrm{n}=18$

\begin{tabular}{|c|c|c|c|c|}
\hline PAHs & Median / $\left(\mu \mathrm{g} \mathrm{kg}^{-1}\right)$ & Minimum / $\left(\mu \mathrm{g} \mathrm{kg}^{-1}\right)$ & Maximum / $\left(\mu \mathrm{g} \mathrm{kg}^{-1}\right)$ & Occurence \\
\hline naphthalene & $<$ LOQ & $<$ LOD & $<$ LOQ & d.n.q. \\
\hline acenaphthylene & $<$ LOQ & $<$ LOD & 2.4 & d.q. \\
\hline acenaphthene & $<$ LOQ & $<$ LOD & 2.2 & d.q. \\
\hline fluorene & $<$ LOQ & $<\mathrm{LOD}$ & 1.8 & d.q. \\
\hline phenanthrene & 2.9 & $<$ LOD & 3.9 & d.q. \\
\hline anthracene & 1.5 & $<\mathrm{LOD}$ & 2.4 & d.q. \\
\hline fluoranthene & $<$ LOD & $<$ LOD & 4.4 & d.q. \\
\hline pyrene & $<$ LOD & $<\mathrm{LOD}$ & 3.3 & d.q. \\
\hline benzo(a)anthracene & 3.8 & $<$ LOD & 5.0 & d.q. \\
\hline chrysene & 6.7 & $<$ LOD & 10.4 & d.q. \\
\hline benzo(b)fluoranthene & 9.6 & $<$ LOD & 11.65 & d.q. \\
\hline benzo(k)fluoranthene & $<$ LOQ & $<$ LOD & 8.0 & d.q. \\
\hline benzo(a)pyrene & $<$ LOQ & $<$ LOD & $<\mathrm{LOQ}$ & d.n.q. \\
\hline indeno(1,2,3-c,d)pyrene & 7.3 & $<$ LOD & 14.0 & d.q. \\
\hline dibenzo(a,h)anthracene & $<\mathrm{LOQ}$ & $<$ LOD & 11.0 & d.q. \\
\hline benzo(g,h,i)perylene & 6.4 & $<$ LOD & 10.2 & d.q. \\
\hline
\end{tabular}

LOD = limit of detection; $\mathrm{LOQ}=$ limit of quantification; d.q. = detected and quantified; d.n.q. = detected and not quantified; n.d. = not detected.

Table S5. Polycyclic aromatic hydrocarbon (PAH) median, minimum and maximum concentrations in the sewage sludge used in SDL1N and SDL8N plots, $\mathrm{n}=18$

\begin{tabular}{|c|c|c|c|c|}
\hline PAHs & Average / $\left(\mu \mathrm{g} \mathrm{kg}^{-1}\right)$ & Minimum / $\left(\mu \mathrm{g} \mathrm{kg}^{-1}\right)$ & Median / $\left(\mu \mathrm{g} \mathrm{kg}^{-1}\right)$ & Maximum / $\left(\mu \mathrm{g} \mathrm{kg}^{-1}\right)$ \\
\hline naphthalene & 51.65 & 20.6 & 49.35 & 88.8 \\
\hline acenaphthylene & 13.52 & $<$ LOD & $<$ LOD & 81.1 \\
\hline acenaphthene & 33.07 & $<$ LOD & 33.5 & 80.8 \\
\hline fluorene & 74.55 & $<\mathrm{LOD}$ & 79.65 & 124.3 \\
\hline phenanthrene & 387.42 & 84.5 & 415.7 & 622.9 \\
\hline anthracene & 25.27 & 8.8 & 15.4 & 82.0 \\
\hline fluoranthene & 78.52 & $<$ LOD & 93.4 & 123.3 \\
\hline pyrene & $<$ LOD & $<$ LOD & $<$ LOD & 161.7 \\
\hline benzo(a)anthracene & 41.05 & $<$ LOD & 43.25 & 90.5 \\
\hline chrysene & 112.93 & 62.2 & 103.2 & 173.4 \\
\hline benzo(b)fluoranthene & 107.95 & $<\mathrm{LOD}$ & 123.15 & 183.0 \\
\hline benzo(k)fluoranthene & 47.32 & $<\mathrm{LOD}$ & 47.8 & 100.5 \\
\hline benzo(a)pyrene & 143.93 & 83.5 & 157.3 & 175.2 \\
\hline indeno(1,2,3-c,d)pyrene & 52.57 & $<\mathrm{LOD}$ & 35.65 & 122.2 \\
\hline dibenzo(a,h)anthracene & 18.13 & $<$ LOD & 6.05 & 81.3 \\
\hline benzo(g,h,i)perylene & 63.37 & $<$ LOD & 42.7 & 176.2 \\
\hline
\end{tabular}


Table S6. Simulation of soil PAH concentrations after ten years of yearly successive applications of sewage sludge rates and simulation of soil PAH limit concentrations in $\mu \mathrm{g} \mathrm{kg}^{-1}$

\begin{tabular}{llll}
\hline PAHs & $\mathrm{C}_{0}^{\mathrm{PAH}}$ & $\mathrm{C}_{10}^{\mathrm{PAH}}$ & $\mathrm{C}_{\infty}^{\mathrm{PAH}}$ \\
\hline naphthalene & 1.83 & 1.84 & 1.84 \\
acenaphthylene & 0.50 & 0.51 & 0.51 \\
acenaphthene & 1.22 & 1.33 & 1.33 \\
fluorene & 2.77 & 2.81 & 2.81 \\
phenanthrene & 14.47 & 20.16 & 20.16 \\
anthracene & 0.94 & 2.22 & 2.23 \\
fluoranthene & 2.94 & 6.71 & 6.73 \\
pyrene & 1.54 & 9.03 & 12.18 \\
benzo(a)anthracene & 1.54 & 4.79 & 4.90 \\
chrysene & 4.24 & 17.33 & 18.79 \\
benzo(b)fluoranthene & 4.05 & 11.74 & 11.93 \\
benzo(k)fluoranthene & 1.78 & 11.04 & 15.93 \\
benzo(a)pyrene & 5.40 & 14.11 & 14.23 \\
indeno(1,2,3-c,d)pyrene & 1.97 & 6.53 & 6.74 \\
dibenzo(a,h)anthracene & 0.68 & 2.69 & 2.88 \\
benzo(g,h,i)perylene & 2.38 & 7.23 & 7.38 \\
$\sum$ PAH & & 120.07 & 130.57 \\
\hline
\end{tabular}

